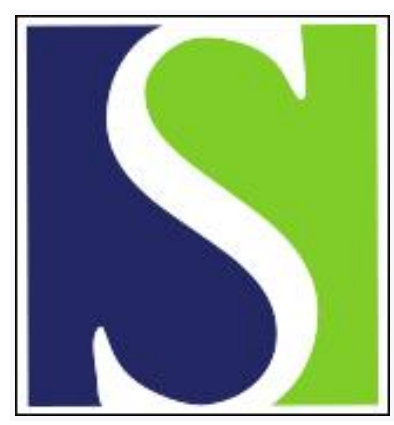

Scand J Work Environ Health 1996;22(2):85-93

https://doi.org/10.5271/sjweh.115

Issue date: Apr 1996

Health risks of electric and magnetic fields caused by high-voltage systems in Finland

by Valjus J

Key terms: biological effects; occupational exposure; practical evaluation; public exposure; review

This article in PubMed: www.ncbi.nlm.nih.gov/pubmed/8738885

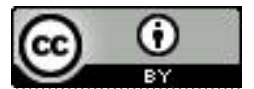




\title{
Health risks of electric and magnetic fields caused by high-voltage systems in Finland
}

\author{
by Jorma Valjus, LMed ${ }^{1}$
}

\begin{abstract}
Valjus J. Health risks of electric and magnetic fields caused by high-voltage systems in Finland. Scand $J$ Work Environ Health 1996;22:85-93.

Health risks of power-frequency electric and magnetic fields (EMF) in the generation and transmission of electric power were investigated in a program comprising nine separate projects. The central objectives were to assess the practical importance of electric and magnetic field exposure as a health risk, to produce data applicable to field management measures at a major power company, and to support and spur research activities on electric and magnetic fields as environmental agents. Electric and magnetic fields seemed to be weak environmental factors, but the findings were uncertain and controversial as to the health risks except that, electric field strengths (about $1.5 \mathrm{kV} \cdot \mathrm{m}^{-1}$ ) found even in the vicinity of $110 \mathrm{kV}$ power lines may cause interference with cardiac pacemakers. There is still a need, however, for further basic research focused on the interaction mechanisms of electric and magnetic fields and biological tissue.
\end{abstract}

Key terms biological effects, occupational exposure, practical evaluation, public exposure, review.

The biological effects and potential health risks of powerfrequency electric and magnetic fields have been studied since the late 1960 s and early 1970 s in many countries. From the viewpoint of the electric utility industry, the subject became important when Korobkova et al (1) presented a report at an international congress on highvoltage electric systems in 1972 (1). According to the report, electric fields may have cardiovascular effects and effects on the central nervous system, as well as effects on the blood count of $500-\mathrm{kV}$ and $750-\mathrm{kV}$ substation workers. The report introduced protective measures, such as screening and the limitation of exposure. A greatly increased international interest in magnetic fields resulted from Wertheimer \& Leeper's publication (2), in 1979 , of results on the elevated risk of cancer, especially leukemia, among people living in the vicinity of power lines.

The importance of the potential health risks associated with the electric and magnetic fields of high-voltage systems was recognized in Finland by the electric utility industry and authorities. Two reviews on the biological effects of the fields were compiled $(3,4)$, of which one was updated in 1995 (5). These reports reflected and continue to reflect the controversiality of the subject. The results of scientific research were mainly addressed to the scientific community and did not provide much help to the electric utility industry, to con- sumers, and, from the viewpoint of occupational exposure, to employees of, for example, energy-intensive industries. The conclusions of these Finnish reviews $(3,4)$ were too indefinite and the information of international reports, for example, those of the World Health Organization $(6,7)$, was too incoherent to allow for characterization of the problem for practical domestic purposes. Imatran Voima Oy, which has been responsible for most of the $110-400 \mathrm{kV}$ national grid in Finland, decided in 1988 to evaluate the importance of electric and magnetic fields as an environmental factor on a more solid empirical basis, that is, through a comprehensive study program.

The objective of the study program (table 1) was to shed light on the problem of electric and magnetic fields by employing a multilevel scientific approach to public and occupational exposure and to the related health risks. Nine study projects were carried out during the years 1988 and 1994 at a total cost of about FIM 10 million, either at the Imatran Voima Oy or in collaboration with several Finnish research institutes, funded at least partly by the company or from assets closely associated with the company's research activities. Three of the nine projects of the program concerned electric and magnetic field exposure, public or occupational, and one was a review of safety guidelines associated with exposure to electric and magnetic fields and their physiological ba-

1 Imatran Voima Oy, Environmental Protection Division, Vantaa, Finland.

Reprint requests to: Mr J Valjus, Imatran Voima Oy, Environmental Protection Division, FIN-01019 IVO, Finland. 
Table 1. The study program.

\begin{tabular}{ll}
\hline Level of approach & Study projects \\
\hline Exposure & $\begin{array}{l}\text { Magnetic fields in Finnish homes (9) } \\
\text { Residential exposure to magnetic fields generated } \\
\text { by } 110-400 \mathrm{kV} \text { power lines in Finland (11, 12) } \\
\text { Exposure to 50-Hz electric and magnetic fields in } \\
\text { high-voltage work (13) }\end{array}$ \\
Safety guidelines of 50/60 Hz electric and magnetic \\
fields and their physiological background (14) \\
Cytogenetic effects & $\begin{array}{l}\text { Analysis of chromosome aberrations, sister } \\
\text { chromatid exchanges, and micronuclei among } \\
\text { power linesmen with long-term exposure to } 50-\mathrm{Hz} \\
\text { electromagnetic fields (20) }\end{array}$ \\
Physiology & $\begin{array}{l}\text { Influence of exposure to low-frequency magnetic } \\
\text { fields on the central nervous system (21) } \\
\text { Influence of the } 50-\mathrm{Hz} \text { electric and magnetic fields } \\
\text { on implanted cardiac pacemakers (23, 24) } \\
\text { Influence of electric and magnetic fields on the } \\
\text { function of the heart and the brain (25) } \\
\text { Risk of cancer in Finnish children living close to } \\
\text { power lines (10) }\end{array}$ \\
\hline
\end{tabular}

sis. One project concerned the cytogenetic effects of electric and magnetic fields in long-term occupational exposure, and three were related to the influence of the fields on human physiological systems. An epidemiologic study was carried out on the risk of childhood cancer near power lines. The study program did not include any reproductive hazards, partly because of the fact that this issue was evaluated as needing basic laboratory research with a teratological approach and partly because of the study reported in 1986 by Algers \& Hultgren (8), who exposed cows in the vicinity of a $400-\mathrm{kV}$ power line with no changes in the reproductive parameters studied.

The practical issues to be investigated were accepted in collaboration with the research institute in question. The study program and its results are presented in this article. In general, the information on the health risks of

Table 2. Magnetic fields in Finnish homes with various sources of magnetic fields. ( $N=60$, averages of $24-\mathrm{h}$ magnetic field recordings)

\begin{tabular}{lc}
\hline Home category & $\begin{array}{c}\text { Magnetic field } \\
(\mu T)\end{array}$ \\
\hline Reference residence & \\
$\quad$ Residences in apartment buildings $(\mathrm{N}=8)$ & 0.066 \\
Single-family houses $(\mathrm{N}=5)$ & 0.080 \\
Residence with electric heating & \\
Ceiling $(\mathrm{N}=6)$ & 0.079 \\
Radiator $(\mathrm{N}=6)$ & 0.11 \\
Floor ( $N=8)$ & 0.16 \\
Residences near external sources & \\
of magnetic fields & \\
$0.4 \mathrm{kV}$ distribution wires $(\mathrm{N}=4)$ & 0.098 \\
$110 \mathrm{kV}$ transmission lines $(\mathrm{N}=6)$ & 0.11 \\
Other ( $N=4)^{\mathrm{b}}$ & 0.14 \\
$10 \mathrm{kV}$ buried cables $(\mathrm{N}=6)$ & 0.15 \\
Indoor distribution transformers $(\mathrm{N}=7)$ & 2.1 \\
\hline
\end{tabular}

a No nearby external sources of magnetic fields, no electric heating.

b Residences $50 \mathrm{~m}$ from a substation $(\mathrm{N}=1)$, near $(20 \mathrm{~m})$ an outdoor distribution transformer $(N=2)$ and near a $10 \mathrm{kV}$ overhead line $(N=1)$. power-frequency electric and magnetic fields has resulted in the development, testing and application of several field management techniques for electric and magnetic field exposure generated by power lines.

\section{Exposure to power-frequency electric and magnetic fields}

The issues of the exposure studies comprised magnetic field exposure in Finnish homes, residential magnetic field exposure in the vicinity of $110-400 \mathrm{kV}$ power lines, occupational exposure to electric and magnetic fields in high-voltage work, and safety guidelines.

\section{Magnetic field exposure in homes}

At the time of the initiation of the study (9) on magnetic field exposure in Finnish homes, there was a need for basic information about public magnetic field exposure in the home environment. There are differences in the national distribution and low-voltage delivery systems (eg, operational voltage, grounding) which weaken the interpretation and application of the results of corresponding foreign studies under the conditions prevailing in Finland. In addition, the study results on magnetic field exposure in reference residences (other than electric heating and no nearby external sources of magnetic field) could be applied in the study program as a reference environment with which the two other studied environments, workplaces of high-voltage systems and the vicinity of $110-400 \mathrm{kV}$ power lines, have been compared. Several types of residences ( 60 in all) with and without external sources of magnetic fields were included. The measurements were carried out in the Kuopio area during the winters of 1987-1988. Table 2 provides the main results of the measurements.

Magnetic field strength in Finnish homes without electric heating and with no nearby external sources of magnetic field is usually below $0.1 \mathrm{~A} \cdot \mathrm{m}^{-1}(9)$, a level which corresponds to the magnetic flux density of $0.13 \mu \mathrm{T}$. To be able to use even numbers in the situation in which magnetic flux density is a more common measure of magnetic field, this statement has been interpreted in the study program so that the magnetic flux density of $0.1 \mu \mathrm{T}\left(0.08 \mathrm{~A} \cdot \mathrm{m}^{-1}\right)$ has been chosen as the maximum of the "normal" magnetic field in Finnish homes. This interpretation is conservative when other electromagnetic environments are compared with magnetic field exposure in homes.

In some residences with electric heating, the magnetic field exposure was found to be higher than in the reference residences. This finding was mainly related to residences equipped with floor heating. The reason for the elevated magnetic field exposure in altogether three 
residences with floor heating was supposed to be singlewire heating cables (9). Certain external sources of magnetic field, such as indoor distribution transformers, may generate a clearly elevated magnetic field in a neighboring residence, even more than a 10 -fold increase in the magnetic flux density compared with the background level of $0.1 \mu \mathrm{T}$ (table 2). Household appliances were found to generate magnetic flux densities up to several tens of microteslas in their immediate $(\leq 0.1 \mathrm{~m})$ vicinity.

\section{Residential exposure in the vicinity of $110-400 \mathrm{kV}$ power lines}

The issue of residential magnetic field exposure of people living in the vicinity of high-voltage power lines was considered important from the general point of view of exposure and, in particular, from the point of view of the risk of childhood cancer, which has been connected with magnetic fields of power lines. A nationwide exposure study, based on a geographic information system and historical load currents, was carried out on residential magnetic field exposure from $110-400 \mathrm{kV}$ power lines of the Finnish national grid. The study was started from the network structure and the average load flows of the year 1989, and it covered the years $1970-1989$. It is connected with the Finnish study on power lines and the risk of childhood cancer (10). The selected exposure evaluation method, based on retrospective calculations, can be justified by the fact that the $110-400 \mathrm{kV}$ national grid was extended and the consumption of electric power increased remarkably during the study period. The other alternatives to assess long-term residential exposure, wire coding and measurements of magnetic flux density, are applicable under more stable conditions and for a limited number of residences.

Two reports have been written $(11,12)$ on this subject. The first, a technical paper focusing on electrical engineering and the grid, was directed towards electrical engineers. The second, focusing on epidemiology and residential exposure, has been targeted toward scientists working within the area of residential magnetic field exposure in the vicinity of power lines. It includes information on, for example, zero-sequence currents and harmonics discussed in the context of a calculation-based evaluation of residential exposure. Table 3 illustrates the distribution of average magnetic flux density in residences of persons living near $110-400 \mathrm{kV}$ lines in the latest study year 1989, which is the most informative from the viewpoint of the present exposure. Compared with the normal magnetic flux density of $0.1 \mu \mathrm{T}$ in Finnish homes, $110-400 \mathrm{kV}$ power lines seem to be the dominant source of residential magnetic field exposure only for relatively few residents living close to the power lines (table 3). Of the total population, the estimated percentage is 0.3 (for $\geq 0.1 \mu \mathrm{T}$ ).

\section{Occupational exposure in high-voltage work}

The motivation for monitoring personal electric and magnetic field exposure in high-voltage work was the environment itself with potentially high exposure. The data on occupational exposure to $50-\mathrm{Hz}$ electric and magnetic fields in high-voltage work were collected using pocketsize personal IREQ dosimeters (Quebec Hydro, Varennes, Quebec, Canada), which recorded electric field strength and magnetic flux density once every $50 \mathrm{~s}$. Table 4 presents the main results of the study (13). When the recorded occupational magnetic field exposure was compared with the "normal" home environment described by Juutilainen et al (9), the occupational exposure in high-voltage work was found to be 10 - to 30 -fold. Magnetic fields up to several hundreds of microteslas were recorded in the vicinity of air-core compensator reactors.

\section{Safety guidelines}

A review of the physiological background and the status of safety guidelines was considered important. The international safety guidelines constitute an upper limit of the exposure scale which practical exposure environments can be compared with and which should not be exceeded. The guidelines referred to in the report by Korpinen \& Partanen (14) were those published by the International Radiation Protection Association (IRPA) in 1990 and those of the standard DIN VDE 0848 published in West Germany in 1989. Of these guidelines, the one of IRPA (15) has been widely adopted more internationally. The DIN VDE 0848 standard has been updated (16), and new safety guidelines have been published by foreign national and international bodies (17-19) (table 5). All these guidelines are based on the basic restriction given by WHO (7) that the intracorporeal current density induced by the fields should not exceed $10 \mathrm{~mA} \cdot \mathrm{m}^{-2}$. In particu-

Table 3. Number of persons living near $110-400 \mathrm{kV}$ lines in Finland in 1989 according to average magnetic flux density $\left(B_{\text {ave }}\right)$.

\begin{tabular}{|c|c|c|c|c|c|c|}
\hline \multirow[t]{2}{*}{ Line voltage $(\mathrm{kV})$} & \multicolumn{6}{|c|}{$\mathrm{B}_{\text {ave }}(\mu \mathrm{T})$} \\
\hline & $0.01-0.09$ & $0.10--0.19$ & $0.20-0.29$ & $0.30-0.49$ & $0.50-0.99$ & $\geq 1.00-$ \\
\hline $\begin{array}{l}110 \\
220 \\
400\end{array}$ & $\begin{array}{r}124889 \\
5217 \\
8186\end{array}$ & $\begin{array}{r}7840 \\
431 \\
674\end{array}$ & $\begin{array}{r}2238 \\
158 \\
207\end{array}$ & $\begin{array}{r}1853 \\
187 \\
121\end{array}$ & $\begin{array}{r}798 \\
82 \\
111\end{array}$ & $\begin{array}{r}327 \\
76 \\
121\end{array}$ \\
\hline Total & 138292 & 8945 & 2603 & 2161 & 991 & 524 \\
\hline
\end{tabular}


Table 4. Electric and magnetic field exposure in typical high-voltage work. IREQ dosimeter: recording time $3-5$ workdays/subject. The electric field strength $(E)$ and the magnetic flux density $(B)$ were calculated from the personal daily average exposure of the subjects for every workplace group: average - median — maximum daily average — short time ( $>3 \mathrm{~min}$ ) maximum during a workday.

\begin{tabular}{|c|c|c|c|c|c|c|c|c|c|c|c|}
\hline \multirow[t]{2}{*}{ Workplace } & \multirow{2}{*}{$\begin{array}{l}\text { Number } \\
\text { of } \\
\text { subjects }\end{array}$} & \multirow{2}{*}{$\begin{array}{c}\text { Number } \\
\text { of } \\
\text { work- } \\
\text { days }\end{array}$} & \multirow{2}{*}{$\begin{array}{l}\text { Recording } \\
\text { time } \\
\text { (h) }\end{array}$} & \multicolumn{4}{|c|}{$E\left(V \cdot m^{-1}\right)$} & \multicolumn{4}{|c|}{$B(\mu T)$} \\
\hline & & & & Mean & Median & $\begin{array}{l}\text { Maximum } \\
\text { daily } \\
\text { average }\end{array}$ & $\begin{array}{l}\text { Short-time } \\
\text { maximum } \\
\text { during a } \\
\text { workday }\end{array}$ & Mean & Median & $\begin{array}{l}\text { Maximum } \\
\text { daily } \\
\text { average }\end{array}$ & $\begin{array}{c}\text { Short-time } \\
\text { maximum } \\
\text { during a } \\
\text { workday }\end{array}$ \\
\hline \multirow{5}{*}{$\begin{array}{l}\text { Control room }(N=4) \\
\text { Power plant }(N=10) \\
\text { Substation }(N=14) \\
\text { Power line }(N=6)\end{array}$} & 9 & 35 & 255 & 13 & 7 & 27 & 1500 & 0.9 & 0.6 & 2.6 & 75 \\
\hline & 45 & 135 & 1000 & 19 & 3 & 480 & 6000 & 1.5 & 0.9 & 11 & 150 \\
\hline & 20 & 74 & 515 & 84 & 31 & 880 & 24000 & $1.4^{\mathrm{a}}$ & $1.1^{\mathrm{a}}$ & 160.5 & $>400$ \\
\hline & 19 & 71 & 495 & 580 & 260 & 3800 & 48000 & 2.6 & 2.6 & 5.6 & 75 \\
\hline & 93 & 315 & 2265 & & & & & & & & \\
\hline
\end{tabular}

a Magnetic flux densities measured in the Alajärvi $400 \mathrm{kV}$ substation close to an air-core compensator reactor are not included as outliers.

Table 5. Safety guidelines for exposure to $50-\mathrm{Hz}$ electric (E) and magnetic (B) fields.

\begin{tabular}{|c|c|c|c|c|c|c|c|c|}
\hline \multirow[t]{3}{*}{ Body } & \multicolumn{4}{|c|}{ Occupational } & \multicolumn{4}{|c|}{ Public } \\
\hline & \multicolumn{2}{|c|}{ Continuous } & \multicolumn{2}{|c|}{ Limited } & \multicolumn{2}{|c|}{ Continuous } & \multicolumn{2}{|c|}{ Limited } \\
\hline & $\left(k V \cdot m^{-1}\right)$ & $\underset{(\mathrm{mT})}{\mathrm{B}}$ & $\left(k V^{E} \cdot m^{-1}\right)$ & $\begin{array}{c}\mathrm{B} \\
(\mathrm{mT})\end{array}$ & $\left(\mathrm{kV} \cdot \mathrm{m}^{-1}\right)$ & $\begin{array}{c}\mathrm{B} \\
(\mathrm{mT})\end{array}$ & $\left(k V \cdot m^{-1}\right)$ & $\begin{array}{c}\mathrm{B} \\
(\mathrm{mT})\end{array}$ \\
\hline IRPA $^{a}$ & $10^{b}$ & $\begin{array}{c}0.5^{\circ} \\
25^{\circ}\end{array}$ & $10-30(t \leq 80 / E)^{e}$ & $5(\max 2 h)$ & $5^{0}$ & $0.1^{\mathrm{d}}$ & $10($ few $h / d)$ & 1 (few h/d) \\
\hline DIN & 21.3 & 1.36 & $\begin{array}{l}40(\leq 2 \mathrm{~h} / \mathrm{d}) \\
66.7(\leq 1 \mathrm{~h} / \mathrm{d})\end{array}$ & $\begin{array}{l}2.55(\leq 2 \mathrm{~h} / \mathrm{d}) \\
4.24(\leq 1 \mathrm{~h} / \mathrm{d})\end{array}$ & 6.7 & 0.42 & & \\
\hline CEC? & 12.3 & 0.4 & & & & & & \\
\hline CENELEC ${ }^{n}$ & 10 & $\begin{array}{l}1.6 \\
25^{e}\end{array}$ & $10-30(t \leq 80 / E)^{\circ}$ & & 10 & $\begin{array}{l}0.64 \\
10^{\mathrm{e}}\end{array}$ & & \\
\hline NRPBi & 12 & 1.6 & & & 12 & 1.6 & & \\
\hline
\end{tabular}

a Recommendation of the International Radiation Protection Association, 1990.

buring an 8-h workday.

c Allowed duration of exposure $t$ is dependent on the electric field strength $E$ between 10 and $30 \mathrm{kV} / \mathrm{m}$.

d Up to $24 \mathrm{~h}$.

e For limbs.

1 National draft for a standard by Deutsche Elektrotechnische Kommission in DIN und VDE (DKE).

9 Amended proposal for a directive by the Commission of the European Communities, 1994.

n Prestandard of the European Committee for Electrotechnical Standardization, 1995.

i Recommendation of the National Radiological Protection Board, 1993.

lar, the values of magnetic flux density of table 5 seem high compared with those of practical situations (tables 2-4). The safety guidelines are set primarily from the viewpoint of acute health outcomes. Observational epidemiologic studies on potential long-term health risks have not been applied as a basis for safety guidelines (14).

\section{Cytogenetic effects}

A study was carried out on the cytogenetic effects of electric and magnetic fields among Finnish power linesmen with considerable long-term exposure to $50-\mathrm{Hz}$ electric and magnetic fields in their occupation (20). The health risk of main interest was an occupational risk of cancer. The number of employees in practical high-voltage work (ie, construction or maintenance of substations or power lines) was too small or too heterogeneous at Imatran Voima Oy to provide a statistical population- based approach. Due to the close relationship between carcinogenesis and mutagenesis, the cytogenetic approach was selected.

Chromosome aberrations, sister chromatid exchange (SCE), and micronuclei in peripheral blood lymphocytes were analyzed among 27 nonsmoking power linesmen and among 27 nonsmoking telephone linesmen (whose exposure to $50-\mathrm{Hz}$ electric and magnetic fields was considered low) serving as referents matched with the exposed workers for age, gender and geographic region. Blood samples from the power linesmen and their individual referents were collected, cultured, and analyzed simultaneously. The frequency of lymphocytes with chromatid-type breaks was higher among the power linesmen $(0.96 \%$ gaps excluded, $1.41 \%$ gaps included) than among the referents $(0.44 \%$ and $0.77 \%$, respectively), but this result was also affected by previous smoking, in addition to exposure to electric and magnetic fields. Exposure or former smoking did not influence the SCE value or the number of micronuclei. The excess of 
aberrant cells was concentrated among the power linesmen who had smoked earlier.

These results suggest that exposure to $50-\mathrm{Hz}$ electric and magnetic fields is associated with a slight increase in chromatid breaks, although the interpretation is somewhat complicated by the confounding effect of previous smoking. It appears that former smokers should not be regarded as nonsmokers in chromosome aberration studies until several years have elapsed after the cessation of smoking.

\section{Effects on physiological systems}

\section{Central nervous system}

Very high (tens of milliteslas) low-frequency magnetic fields have well-known neurophysiological effects (magnetophosphenes). From the viewpoint of occupational exposure and related safety aspects it was considered important to study the effects of low-frequency magnetic fields on the central nervous system. A study on the effects of the $45-\mathrm{Hz}$ sinusoidal magnetic fields on brain functions was performed (21).

In the study, 10 volunteers were exposed to a continuous magnetic flux density of $1.2 \mathrm{mT}$ and 10 were exposed to an intermittent ( $1 \mathrm{~s}$ on $1 \mathrm{~s}$ off) form. Each person received one real and one sham exposure. The electroencephalographic (EEG) results and reaction time served as the measures of the neurophysiological effects. Generally, a tendency of the moving of the EEG frequency distribution towards higher frequencies was observed, particularly after intermittent exposure. No increase or decrease in the exposure frequency was observed in the EEG spectrum. Thus nothing supported the possible synchronization of the electrical activity of the brain with the frequency of the exposure. There was no difference in the preexposure and postexposure reaction times. However, magnetic field exposure seemed to affect learning on the reaction-time test. Those who were exposed to sham fields improved their performance in the reaction-time test normally, whereas those who were exposed to real fields improved their performance only very little. This observation was repeated in another test series.

However, the observed findings were within normal physiological variations (21). No conclusions could be drawn as to the hazardous effects of the fields on the central nervous system, but the interpretation of decreased activeness or relaxation of the central nervous system due to exposure to $45-\mathrm{Hz}$ magnetic fields was referred to in the report by Lyskov et al (21).

\section{Cardiac pacemakers}

Since the beginning of synchronized pacing, electromagnetic interference has been a problem to the sensing mechanism of cardiac pacemakers (22). A Finnish example of such interference was a farmer who, according to his own statement, could not work because of chest pain in areas of his farm that were located close to a $400 \mathrm{kV}$ power line running through his land. This patient case and the fact that there are about 10000 cardiac pacemaker patients in Finland, roughly two-thirds of whom are capable of physical activity (Dr L Toivonen, personal communication) and may occasionally be exposed to electric and magnetic fields from environmental sources, created a need to expose selected Finnish pacemaker patients to $50-\mathrm{Hz}$ electric and magnetic fields in controlled situations.

The exposure circumstances in the performed study imitated the vicinity of $110-400 \mathrm{kV}$ power lines with both electric and magnetic field exposure. In addition, more extreme exposure areas, dominated by a strong magnetic or electric field, were selected. Telemetric electrocardiography was used to register the cardiac function of the patients. Two reports were published $(23,24)$, one of which was directed towards cardiologists and the other, being more general, concentrated on readers without medical education. All the 15 subjects with 12 different pacemaker models had a reliable spontaneous heart rhythm. During the study of premature pacings, the pacing rate of the pacemaker was adjusted to be below the spontaneous heart rate of the patient in question, and all the recorded heart beats should have been spontaneous. When inhibited pacings were studied, the pacing rate of the pacemaker was higher than the spontaneous heart rate of the patient, and all the heart beats should have been triggered by the pacemaker. The measure of pacing disturbances was the appearance of premature pacings or, on the other hand, the inhibition of pacing, when these should not have occurred. Table 6 summarizes the results of the study.

In the study, the following three main issues were evaluated: the relevance of magnetic field exposure versus electric field exposure, the role of lead configuration (bipolar versus unipolar), and the effect of the programmed sensitivity (expressed regular versus high in table 6). All the studied pacemakers measured the function of the ventricles where the pacing electrode(s) were located (the apex of the right ventricle) [ie, the studied pacing mode was the most common ventricular-on-demand (VVI)]. As presented in table 6, the abnormal pacings were more related to electric field exposure, even in low electric fields $(1.2-1.7 \mathrm{kV} / \mathrm{m})$ that exist near $110-\mathrm{kV}$ power lines, to unipolar lead configurations, and to pacemakers with high programmed sensitivity of the measuring function. In the studied circumstances, magnetic field exposure seemed to be a minor source of pacemaker interference. No tests with pacemakers measuring atrial sensitivity were carried out.

Scand J Work Environ Health 1996, vol 22, no 2 
Table 6. Recorded pacing abnormalities. Notation, for example, 1/15, means that an abnormal pacing (premature or inhibited) was found in one pacemaker of the 15 tested.

\begin{tabular}{|c|c|c|c|c|c|c|}
\hline \multirow{4}{*}{$\begin{array}{l}\text { Pacing abnormalities } \\
\text { and exposurea }\end{array}$} & \multicolumn{6}{|c|}{ Lead configuration } \\
\hline & \multicolumn{4}{|c|}{ Unipolar } & \multirow{2}{*}{\multicolumn{2}{|c|}{$\frac{\text { Bipolarb }}{\text { High sensitivily }}$}} \\
\hline & \multicolumn{2}{|c|}{ Regular sensitivity } & \multicolumn{2}{|c|}{ High sensitivity } & & \\
\hline & $\begin{array}{l}\text { Moderate } \\
\text { electric fieldc }\end{array}$ & $\begin{array}{l}\text { Strong } \\
\text { electric field }\end{array}$ & $\begin{array}{l}\text { Moderate } \\
\text { electric field }\end{array}$ & $\begin{array}{c}\text { Strong } \\
\text { electric field }\end{array}$ & $\begin{array}{l}\text { Moderate } \\
\text { electric field }\end{array}$ & $\begin{array}{l}\text { Strong } \\
\text { electric fieldd }\end{array}$ \\
\hline Premature & $1 / 15$ & $6 / 15$ & $5 / 12$ & $9 / 12$ & $0 / 4$ & $0 / 4$ \\
\hline Inhibitede & $1 / 15$ & $5 / 15$ & $6 / 12$ & $2 / 12$ & $0 / 4$ & $1 / 4$ \\
\hline
\end{tabular}

Patients having bipolar pacemakers set to low sensitivity seem to be reasonably well protected against asystoles, even in circumstances that have recently not been recommended to pacemaker patients. Tailoring the pacemaker features according to individual needs diminishes the necessity to restrict the patients' activities in surroundings with elevated electromagnetic fields (23).

\section{Effects on the cardiovascular and autonomic nervous systems}

A study was performed on the effects of electric and magnetic fields on the cardiovascular and autonomic nervous systems. From the viewpoint of the electric utility industry, the incentive of the study was the interest in receiving empirical information on the issue of whether an external electric source (eg, a high-voltage system) can interfere with a biological electric system. After the primary report $(25)$, two scientific articles $(26,27)$ have been published. Attempts were also made to apply ambulatory EEG under field conditions to study the effects of electric and magnetic fields on brain functions. This part of the study met severe technical problems, as described by Korpinen et al (25), and the results cannot be utilized for practical evaluations so far.

In the study, 41 volunteers were exposed to electric and magnetic fields in the vicinity of a $400 \mathrm{kV}$ line and in the area of the high-voltage testing laboratory of the Tampere University of Technology. No alterations in the standardized tests on the function of the autonomic nervous system (Valsalva, deep breathing test, orthostatic test) and in heart rate were observed. An analysis of the electrocardiogram showed that cardiac extrasystoles or arrhythmias where as frequent inside the field as outside the field. A minor difference in the diastolic blood pressure was observed between the exposed and the sham exposed, but the finding was questionable due to the wide distribution of the results of the blood pressure measurements.

\section{Childhood cancer and power lines}

Internationally, the relative risk of childhood cancer in the vicinity of power lines is one of the main issues in the research on the biological effects of electric and magnetic fields. The Finnish cohort study (10) was nationwide and covered the years from 1974 to 1990 . Two exposure criteria, annual average magnetic field and cumulative magnetic field exposure, were selected. The cohort consisted of 135000 children and adolescents living or having lived within a $500-\mathrm{m}$ distance from a $110-400 \mathrm{kV}$ power line and exposed to an annual average magnetic field of $\geq 0.01 \mu \mathrm{T}$. The children were followed for cancer in 1974-1990 up to the age of 19 years. The included $110-400 \mathrm{kV}$ lines covered $90 \%$ of the total line length in 1989. A detailed description of methods applied in the residential exposure evaluation has been presented by Valjus et al (12). Two cutpoints were applied: $0.2 \mu \mathrm{T}$ for the annual average magnetic field exposure and $0.4 \mu \mathrm{T}$ years for the cumulative exposure. Table 7 presents the main results of the study.

The conclusive summary of this important and sensitive issue was formed by Verkasalo et al (10) as follows: "The study showed no significant increase in the incidence of leukaemia, lymphoma, or cancers overall in children exposed to residential magnetic fields from power transmission lines in Finland. The significant increase in the incidence of nervous system tumors in boys (when the sexes were given separately) is likely to be a chance finding. The results suggest that the risk of childhood cancer in the vicinity of these power lines is not a major public health concern. The relation between a risk of childhood cancer and exceptionally high levels of residential exposure to magnetic fields should not, however, be inferred from this study [p 899]." The results of Ahlbom et al (28) in which the findings of the three Nordic studies $(10,29,30)$ on power lines and childhood cancer are pooled, support the conclusion not to rule out the 
Table 7. Observed $(0)$ and expected $(E)$ cases of cancer in children with standardized incidence ratios (SIR) and $95 \%$ confidence intervals $(95 \% \mathrm{Cl})$ by primary site, in relation to annual average magnetic field exposure and cumulative magnetic field exposure.

\begin{tabular}{|c|c|c|c|c|c|c|c|c|c|c|}
\hline \multirow[t]{3}{*}{ Cancer } & \multicolumn{5}{|c|}{ Annual average exposure } & \multicolumn{5}{|c|}{ Cumulative exposure } \\
\hline & \multirow{2}{*}{$\begin{array}{l}\text { Magnetic field } \\
(\mu T)\end{array}$} & \multicolumn{2}{|c|}{ Cancer cases } & \multirow[t]{2}{*}{$\mathrm{SIR}$} & \multirow[t]{2}{*}{$95 \% \mathrm{Cl}$} & \multirow{2}{*}{$\begin{array}{l}\text { Cumulative } \\
(\mu T) \text { years }\end{array}$} & \multicolumn{2}{|c|}{ Cancer cases } & \multirow[t]{2}{*}{ SIR } & \multirow[t]{2}{*}{$95 \% \mathrm{Cl}$} \\
\hline & & $\begin{array}{l}\text { Ob- } \\
\text { served } \\
\text { (N) }\end{array}$ & $\begin{array}{c}\text { Ex- } \\
\text { pected } \\
\text { (N) }\end{array}$ & & & & $\begin{array}{l}\text { Ob- } \\
\text { served } \\
\text { (N) }\end{array}$ & $\begin{array}{l}\text { Ex- } \\
\text { pected } \\
\text { (N) }\end{array}$ & & \\
\hline Overall cancer & $\begin{array}{l}0.01-0.19 \\
\geq 0.20\end{array}$ & $\begin{array}{r}129 \\
11\end{array}$ & $\begin{array}{r}137.17 \\
7.39\end{array}$ & $\begin{array}{l}0.94 \\
1.5\end{array}$ & $\begin{array}{l}0.99-1.1 \\
0.74-2.7\end{array}$ & $\begin{array}{l}0.01-0.39 \\
\geq 0.40\end{array}$ & $\begin{array}{r}125 \\
15\end{array}$ & $\begin{array}{r}133.73 \\
10.96\end{array}$ & $\begin{array}{l}0.93 \\
1.4\end{array}$ & $\begin{array}{l}0.78-1.1 \\
0.77-2.3\end{array}$ \\
\hline Nervous system tumors & $\begin{array}{l}0.01-0.19 \\
\geq 0.20\end{array}$ & $\begin{array}{r}34 \\
5\end{array}$ & $\begin{array}{r}39.82 \\
2.16\end{array}$ & $\begin{array}{l}0.85 \\
2.3\end{array}$ & $\begin{array}{l}0.59-1.2 \\
0.75-5.4\end{array}$ & $\begin{array}{l}0.01-0.39 \\
\geq 0.40\end{array}$ & $\begin{array}{r}32 \\
7\end{array}$ & $\begin{array}{r}38.80 \\
2.98\end{array}$ & $\begin{array}{l}0.82 \\
2.3\end{array}$ & $\begin{array}{l}0.56-1.2 \\
0.94-4.8\end{array}$ \\
\hline Leukemia & $\begin{array}{l}0.01-0.19 \\
\geq 0.20\end{array}$ & $\begin{array}{c}32 \\
3\end{array}$ & $\begin{array}{r}36.10 \\
1.93\end{array}$ & $\begin{array}{l}0.89 \\
1.6\end{array}$ & $\begin{array}{l}0.61-1.3 \\
0.32-4.5\end{array}$ & $\begin{array}{l}0.01-0.39 \\
\geq 0.40\end{array}$ & $\begin{array}{r}32 \\
3\end{array}$ & $\begin{array}{r}35.60 \\
2.43\end{array}$ & $\begin{array}{l}0.90 \\
1.2\end{array}$ & $\begin{array}{l}0.62-1.3 \\
0.26-3.6\end{array}$ \\
\hline Lymphoma & $\begin{array}{l}0.01-0.19 \\
\geq 0.20\end{array}$ & $\frac{15}{-}$ & $\begin{array}{r}16.55 \\
0.88\end{array}$ & 0.91 & $\begin{array}{r}0.51-1.5 \\
0-4.2\end{array}$ & $\begin{array}{l}0.01-0.39 \\
\geq 0.40\end{array}$ & $\begin{array}{r}14 \\
1\end{array}$ & $\begin{array}{r}15.87 \\
1.56\end{array}$ & $\begin{array}{l}0.88 \\
0.64\end{array}$ & $\begin{array}{r}0.48-1.5 \\
0.016-3.6\end{array}$ \\
\hline Other sites & $\begin{array}{l}0.01-0.19 \\
\geq 0.20\end{array}$ & $\begin{array}{r}48 \\
3\end{array}$ & $\begin{array}{r}44.70 \\
2.42\end{array}$ & $\begin{array}{l}1.1 \\
1.2\end{array}$ & $\begin{array}{l}0.79-1.4 \\
0.26-3.6\end{array}$ & $\begin{array}{l}0.01-0.39 \\
\geq 0.40\end{array}$ & $\begin{array}{r}47 \\
4\end{array}$ & $\begin{array}{r}43.46 \\
3.99\end{array}$ & $\begin{array}{l}1.1 \\
1.0\end{array}$ & $\begin{array}{l}0.80-1.4 \\
0.27-2.6\end{array}$ \\
\hline
\end{tabular}

possibility of increased risk of childhood cancer in the vicinity of power lines.

\section{Discussion and conclusions}

\section{Exposure and safety guidelines}

Single-wire floor heating cables may be a notable source of magnetic fields in the home environment. However, they are installed very rarely nowadays, and in practice modern bifilar heating cables dominate. The general assumption that the level of magnetic fields in residences with electric heating is not elevated when compared with reference residences was accepted, and no exclusion of residences was made on the basis of the heating system in the study by Verkasalo et al (10). Power lines of $110-400 \mathrm{kV}$ are not the main source of magnetic field exposure, as shown by a comparison of the normal magnetic flux density of $0.1 \mu \mathrm{T}$ in Finnish homes (9) with the residential exposure generated by power lines (table 3 ). A comparison of public and occupational exposure led to the conclusion that occupational exposure in Finland may evidently be 10-30 times higher despite the fact that no work is done on live high-voltage systems. In certain, although rare, workplaces the safety guidelines of the IRPA may be exceeded. In public exposure, the guidelines of the IRPA are hardly exceeded. An electric field, contrary to a magnetic field, does not penetrate building materials. Indoor $110 \mathrm{kV}$ systems are rare, or the switchgear is metal-clad (systems insulated with sulfur hexafluoride). Thus high exposure to electric fields is unlikely in places other than outdoors in the vicinity of highvoltage power lines, and, occupationally, also in highvoltage substations. Air-core compensator reactors are nowadays fenced against accidental approach in the highvoltage substation areas.
The coverage of the existing exposure studies is limited. There are many important exposure environments without data that are potentially worth studying (eg, 10$20 \mathrm{kV}$ distribution systems, environments of energy-consuming industrial processes and electric transport systems). The task of creating a more complete picture of magnetic field exposure in particular was assessed to be important, both generally and from the viewpoint of exposure evaluation for further epidemiologic studies on health outcomes. Due to the complexity of the task, it should probably be based both on domestic measurements and on existing exposure data, especially from Sweden, where the generation, transmission, distribution, and low-voltage delivery of electric energy is very similar to those of Finland.

\section{Health risks}

No doubt, there may be interference between a highvoltage system and cardiac pacemakers, and in certain cases there is a potential need for clinical considerations. The nature of this connection is primarily technical, between two electric systems. Secondary health effects were considered possible, though unlikely, due to the redundancy built into modern pacemakers. The aspects that cardiologists should consider implanting bipolar pacemakers instead of unipolar ones, which are less sensitive to interference, and avoiding programming the sensitivity of unipolar pacemakers higher than is physiologically necessary in cases of essential $50-\mathrm{Hz}$ electric and magnetic field exposure. Atrial or dual-chamber pacemakers, which also measure atrial activity, were not studied by Toivonen et al (23). Such pacemakers are probably sensitive to electric and magnetic field interference, due to the low muscle mass of atria requiring high measuring sensitivity.

The internationally observed risk of childhood cancer (although not usually statistically significant) in the 
vicinity of power lines is generally below 3 as presented by Korpinen et al (5) and, for example, by Ahlbom et al (28). This assessment conforms with the data in table 7 showing the highest standardized incidence ratio of 2.3 . The risk of childhood cancer in the vicinity of $110-400$ $\mathrm{kV}$ power lines in Finland can be graded roughly on the basis of table 7 by dividing the difference of the observed and expected cases of the higher exposure categories by the study period of 17 years for the evaluation of the annual number of extra cases, the result being an excess number of 0.21 per year for total childhood cancers and, for example, 0.06 per year for leukemia. This procedure grades the problem from two points of view. Epidemiologically, it seems extremely difficult to obtain a sufficiently large population, exposed clearly over the "normal" magnetic field of $0.1 \mu \mathrm{T}$ in the vicinity of power lines, for studies with sufficient statistical power, and, in practice, the minor scale of the problem in the vicinity of Finnish power lines, even though one extra childhood cancer would be ethically too many.

So far, it is believed that the effects of magnetic fields on the central nervous system need more basic research before any practical safety measures can be taken. The studied magnetic flux density of $1.2 \mathrm{mT}$ is extremely high, and in practice it is probably only met in high-voltage systems near air-core compensator reactors (1). Thus the findings of the study by Lyskov et al (21) currently have hardly any clinical significance.

Assessing the cytogenetic effects of electric and magnetic fields on the basis of the findings of Valjus et al (20) is for practical purposes difficult. The possibilities to extrapolate the findings up to the level of human health are limited. Both electric and magnetic field exposure and previous, perhaps years ago, smoking seem to affect the observed chromosome aberrations. In addition these two factors can be considered equally potent. The observed effect is more likely a sign of a biological effect than a sign of a health risk. Practical assessment emphasizes the need for further research into cytogenetic effects and a prospective study of the issue, instead of the initiation of new concrete occupational safety measures.

\section{Field management measures}

It is questionable whether there are health risks associated with power-frequency electric and magnetic field exposure that would require the electric utility industry to respond by implementing field-decreasing technical solutions to fields present in practical occupational and residential settings. However, the continuous uncertainty about the issue has led to several technical magnetic field management measures, so far mainly directed towards decreasing public exposure to magnetic fields from power lines (31). However, it has been concluded that there is no need to carry out any major measures in the existing $110-400 \mathrm{kV}$ network. The performed management measures include optimal conductor suspension in double-circuit lines (also reinstallations in existing lines), checking of the magnetic fields of new lines at the planning stage, and an extended building exclusion zone in the vicinity of new lines ( $\mathrm{eg}$, from 18 to $23 \mathrm{~m}$ in the case of a $110-\mathrm{kV}$ line). In addition, the following special solutions to decrease environmental fields have been studied, tested or applied: an 110-kV urban test line with coated conductors, narrow and high low-field towers with special, often vertical conductor suspension, a compact very low-field urban tower, and an active full-scale magnetic field canceling system for single family houses.

\section{Concluding remarks}

In light of the study program, power-frequency electric and magnetic fields can be considered not to be a major health concern. The only finding which may be of clinical importance is pacemaker interference in electric fields even of the order prevailing near $110-\mathrm{kV}$ lines. However, the possibility of health effects caused by power-frequency electric and magnetic fields should be taken into account. The electric utility industry has to cope with the uncertainty of the issue.

From the viewpoint of further research on the health effects of power-frequency electric and magnetic fields, issues related to the effects of the fields in animal models and to the basic interaction mechanisms of the fields in vitro seem to be better topics for the electric utility industry than issues related to observational epidemiology, if populations large enough and subjected to considerable and well-characterized magnetic field exposure cannot be established.

\section{Acknowledgments}

The cross-scientific study program required comprehensive and long-term collaboration within Imatran Voima Oy and with the Department of Public Health of the University of Helsinki, the Finnish Cancer Registry, the Finnish Institute of Occupational Health, the Department of Environmental Sciences of the University of Kuopio, the Tampere University of Technology (Electric Power Utilization), the First Department of Medicine of the Helsinki University Central Hospital, and the Finnish Center for Radiation and Nuclear Safety, which were the primary collaborators in the program. In addition, several other counterparts provided valuable professional assistance. The author wishes to thank all those who have participated in the study program for their interest, professional contribution, and collaboration. 


\section{References}

1. Korobkova V, Mozorov Y, Stolarov M, Yakub Y. Influence of the electric field in 500 and $750 \mathrm{kV}$ switchyard on maintenance staff and means for its protection. Presented at the Conference on Large High Voltage Electric Systems, 28 August-6 September 1972. Paper 23-06.

2. Wertheimer $\mathrm{N}$, Leeper E. Electrical wiring configurations and childhood cancer. Am J Epidemiol 1979;109:273-84.

3. Valjus J. Pientaajuisten sähkö- ja magneettikenttien fysiologiset vaikutukset [Physiological effects of low-frequency electric and magnetic fields]. Helsinki: Imatran Voima Oy, 1987. Tutkimusraportti IVO-A-04/87. Summary in English.

4. Hietanen M, Anttonen H, Jokela K, Juutilainen J. Voimajohtojen sähkö- ja magneettikenttien biologiset vaikutukset ja terveyshaitat [Biological effects and health risks of the electric and magnetic fields generated by power lines]. Helsinki: Kauppa- ja teollisuusministeriö, 1988. Energiaosaston julkaisuja, sarja D:159. Summary in English

5. Korpinen L, Hietanen M, Jokela K, Juutilainen J, Valjus J. Voimajohtojen sähkö- ja magneettikentät ympäristössä [Environmental electric and magnetic fields generated by power lines]. Helsinki: Kauppa- ja teollisuusministeriö, 1995. Tutkimuksia ja raportteja 89. Summary in English

6. World Health Organization (WHO). Extremely low frequency (ELF) fields. Geneva: WHO, 1984. Environmental health criteria 35.

7. World Health Organization (WHO). Magnetic fields. Geneva: WHO, 1987. Environmental health criteria 69.

8. Algers B, Hultgren J. Effects of long-term exposure to a 400 $\mathrm{kV}, 50 \mathrm{~Hz}$ transmission line on estrous, fertility and diurnal rhythm in cows. Skara (Sweden): Sveriges Lantbruksuniversitet, Veterinärmedicinska fakulteten 1986. Rapport 15.

9. Juutilainen J, Saali K, Eskelinen J, Matilainen P, Leinonen A-L. Measurements of $50 \mathrm{~Hz}$ magnetic fields in Finnish homes. Helsinki: Imatran Voima Oy, 1989. Research report IVO-A-2/89.

10. Verkasalo P, Pukkala E, Hongisto M, Valjus J, Järvinen $P$, Heikkilä K, et al. Risk of cancer in Finnish children living close to power lines. Br Med J 1993;307:895-9.

11. Hongisto M, Valjus J. Magnetic field exposure in the vicinity of the national grid of Finland. Presented at the Conference on Large High Voltage Electric Systems, 28 August-3 September 1994. Paper 36-104.

12. Valjus J, Hongisto $M$, Verkasalo $P$, Järvinen $P$, Heikkilä $K$, Koskenvuo M. Residential exposure to magnetic fields generated by $110-400 \mathrm{kV}$ power lines in Finland. Bioelectromagnetics. 1995;16:365-76.

13. Mäkinen P, Järvinen P, Valjus J, $50 \mathrm{~Hz}$ sähkö- ja magneettikenttäaltistus suurjännitetöissä [Exposure to $50 \mathrm{~Hz}$ electric and magnetic fields in high-voltage work]. Helsinki: Imatran Voima Oy, 1991. Tutkimusraportti IVO-A-01/91. Summary in English.

14. Korpinen L, Partanen J. 50/60 Hz sähkö- ja magneettikenttien fysiologiset vaikutukset ja niitä koskevat määräykset [Physiological effects and safety guidelines of 50/60 $\mathrm{Hz}$ electric and magnetic fields]. Helsinki: Imatran Voima Oy, 1990. Tutkimusraportti IVO-A-01/90. Summary in English.

15. International Non-ionizing Radiation Committee of the International Radiation Protection Association (IRPA/INIRC). Interim guidelines on limits of exposure to $50 / 60 \mathrm{~Hz}$ electric and magnetic fields. Health Phys 1990;58:113 — 22.
16. Deutsche Elektrotechnische Kommission in DIN und VDE (DKE). Sicherheit in Electromagnetischen Feldern. Entwurf DIN VDE 0848 Teil 4 A3. Ersatz für Entfurf DIN VDE 0848 Teil 4 A2/12.91.

17. Commission of the European Communities (CEC). Amended proposal for a Council directive on the minimum health and safety requirements regarding the exposure of workers to the risks arising from physical agents. Off J Eur Communities C 1994;37:C230.

18. European Committee for Electrotechnical Standardization (CENELEC). Human exposure to electromagnetic fields: low frequency $(0 \mathrm{~Hz}$ to $10 \mathrm{kHz}$ ). Brussels: CENELEC, 1995. European prestandard ENV 50166 1, 1995.

19. National Radiation Protection Board (NRPB). Board statement on restrictions on human exposure to static and time varying electromagnetic fields and radiation. Chilton (Didcot): NRPB, 1993. Documents of the NRPB; vol 4, no 5, 1993.

20. Valjus J, Norppa H, Järventaus H, Sorsa M, Nykyri E, Salomaa $S$, et al. Analysis of chromosomal aberrations, sister chromatid exchanges and micronuclei among power linesmen with long-term exposure to $50-\mathrm{Hz}$ electromagnetic fields. Radiat Environ Biophys 1993;32:325-36.

21. Lyskov E, Juutilainen J, Jousmäki V, Partanen J, Medvedev S, Hänninen $\mathrm{O}$. Effects of $45-\mathrm{Hz}$ magnetic fields on the functional state of the human brain. Bioelectromagnetics 1993;14: $87-95$.

22. Irnich W. Interference in pacemakers. PACE 1984;7:102147.

23. Toivonen L, Valjus J, Hongisto M, Metso R. The influence of the $50 \mathrm{~Hz}$ electric and magnetic fields on implanted cardiac pacemakers: the role of the lead configuration and programming of the sensitivity. PACE 1991;14:2114-22.

24. Toivonen L, Valjus J, Hongisto M, Metso R. Cardiac pacemakers in $50 \mathrm{~Hz}$ electric and magnetic fields. Helsinki: Imatran Voima Oy, 1991. Research report IVO-A-04/91.

25. Korpinen L, Partanen J. Sähkö- ja magneettikenttien vaikutus sydämen ja aivojen toimintaan [The influence of electric and magnetic fields on the function of the heart and brain]. Tampere (Finland): Tampereen teknillinen korkeakoulu, Sähkönkäyttötekniikka 1993. Raportti 1-93. Summary in English.

26. Korpinen L, Partanen J, Uusitalo A. Influence of $50 \mathrm{~Hz}$ electric and magnetic fields on the human heart. Bioelectromagnetics 1993;14:329-40.

27. Korpinen L, Partanen J. Influence of $50 \mathrm{~Hz}$ electric and magnetic fields on the pulse rate of human heart. Bioelectromagneties 1994;15:503-12.

28. Ahlbom A, Feychting M, Koskenvuo M, Olsen J, Pukkala E, Schulgen $\mathrm{G}$, et al. Electromagnetic fields and childhood cancer [letter]. Lancet 1993;342:1295-6.

29. Olsen J, Nielsen A, Schulgen G. Residence near high-voltage facilities and the risk of cancer in children. Br Med $\mathrm{J}$ 1993;307:891-5

30. Feychting M, Ahlbom A. Magnetic fields and cancer in children living close to Swedish high-voltage power lines. Am J Epidemiol 1993; 138:467-81.

31. Vuola R. Voimajohtojen aiheuttamien magneettikenttien pienentämismahdollisuudet [The reduction of the magnetic fields produced by power lines]. Helsinki: Helsingin teknillinen korkeakoulu, Sähkötekniikan osasto, 1993. Summary in English.

Received for publication: 10 August 1995 